\title{
CATATAN DARING MATEMATIKA: PELATIHAN PEMANFAATAN GOOGLE SITE SEBAGAI MEDIA PEMBELAJARAN DARING
}

\author{
Sugama Maskar ${ }^{1}$, Nicky Dwi Puspaningtyas ${ }^{2}$, Clara Fatimah $^{3}$, Intan Mauliya $^{4}$ \\ ${ }^{1,2,3,4)}$ Program Studi Pendidikan Matematika, Fakultas Sastra dan Ilmu Pendidikan, \\ Universitas Teknokrat Indonesia \\ e-mail:sugama_maskar@teknokrat.ac.id
}

\begin{abstract}
Abstrak
Tujuan pelaksanaan kegiatan pelatihan pemanfaatan Google Site sebagai Media Pembelajaran daring di SMA Islam Global Surya Lampung ini adalah untuk meningkatkan pemahaman dan keterampilan penggunaan Google Site sebagai media untuk mengoptimalkan proses pembealajaran daring di era pandemi Covid-19 saat ini. Kegiatan dilaksanakan di SMA Islam Global Surya, Kota Bandar Lampung, Provinsi Lampung selama periode Februari sampai dengan Maret 2021 dengan empat pertemuan serta 20 siswa. Metode evaluasi hasil pelatihan diukur dengan menggunakan metode kuantitatif dan kualitatif dengan instrumen tes awal (pre-test), tes akhir (post-test) dan angket respon siswa. Pengolahan hasil data tes digunakan teknik statistik deskriptif dan inferensial menggunakan uji-t atau Independent sampel t-test. Sedangkan pengolahan dan analisa data angket respon siswa menggunakan statistik deskriptif dan studi literatur melalui sumber yang relevan. Hasil uji data instrumen tes menunjukan bahwa rerata siswa sebelum dan setelah melaksanakan pelatihan meningkat dari 74.6 ke 84.1 dengan simpangan baku sebesar 7.48 dan 7.39. Nilai tersebut juga dibuktikan dengan uji-t, dimana nilai P-Valuenya sebesar 0.000 . Artinya dengan nilai $=5 \%$, nilai $\mathrm{P}$-Value tersebut menunjukan bahwa terdapat perbedaan yang signifikan rerata sebelum dan setelah pelaksanaan pelatihan. Informasi tersebut didukung oleh hasil angket siswa yang menunjukan bahwa lebihd ari $80 \%$ siswa merespon telah memahami penggunaan dan pemanfaatan catatan daring menggunakan Google Site.
\end{abstract}

Kata Kunci: Catatan Pembelajaran, Google Site, Pembelajaran Daring.

\begin{abstract}
The purpose of this training activity on the use of Google Site as an online Learning Media at SMA Islam Global Surya Lampung is to improve understanding and skills in using Google Site as a medium to optimize the online learning process in the current Covid-19 pandemic era. The activity was carried out at Global Surya Islamic High School, Bandar Lampung City, Lampung Province during the period from February to March 2021 with four meetings and 20 students. The method of evaluating the results of the training was measured using quantitative and qualitative methods with the instruments of an initial test (pre-test), a final test (post-test) and student response questionnaires. Processing of test data results used descriptive and inferential statistical techniques using t-test or Independent sample t-test. Meanwhile, the processing and analysis of student response questionnaire data used descriptive statistics and literature studies through relevant sources. The test results of the test instrument data showed that the mean of students before and after carrying out the training increased from 74.6 to 84.1 with standard deviations of 7.48 and 7.39. This value is also proven by the $\mathrm{t}$-test, where the P-Value is 0.000 . This means that with a value of $=5 \%$, the P-Value value shows that there is a significant difference in the mean before and after the training. This information is supported by the results of student questionnaires which show that more than $80 \%$ of students responding have understood the use and utilization of online notes using the Google Site.
\end{abstract}

Keywords: Academic Diary, Google Site, Online Learning

\section{PENDAHULUAN}

Seluruh dunia mengalami krisis kesehatan dengan adanya pandemi Covid-19 yang dimulai awal Maret 2020, tidak terkeculai di Indonesia. Sebagai upaya pencegahan dan penanganan pandemi tersebut, Pemerintah Indonesia melalui Kementrian Pendidikan dan Kebudayaan 
(Kemendikbud) mengeluarkan surat edaran No. 3 tahun 2020 yang berisikan himbauan agar pembelajaran dilaksanakan via daring agar menghindari kontak fisik dan kerumunan. Pemerintah juga memberikan fasilitas beberpa media pembelajaran daring serta memberikan subsidi kuota bagi masyarakat di bawah Kemendikbud (Kemendibud, 2020).

Perubahan tersebut memberikan dampak, baik langsung maupun tidak langsung, terhadap proses, kebiasaan, dan mental siswa maupun guru dalam melaksanakan proses pembelajaran. Selain itu, permasalahan terbatasnya kuota dan sulitnya signal internet di beberapa tempat merupakan suatu permasalahan yang sulit dicarikan solusinya secara cepat (Maskar \& Wulantina, 2019). Namun, pembelajaran daring juga memberikan sisi positif, yaitu pembelajaran dapat dilakukan di mana saja tidak terbatas oleh ruang dan waktu. Lebih jauh pembelajaran daring juga menuntut siswa menjadi pembelajar mandiri, sesuatu yang sulit dilakukan pada mode pembelajaran konvensional (Ulfa \& Puspaningtyas, 2020; Puspaningtyas \& Putri, 2020).

Kemandirian belajar memang merupakan sesuatu yang positif yang dapat ditawarkan dan merupakan suatu pengalalaman yang baik bagi siswa pada saat melaksanakan pembelajaran secara daring. Namun demikian, mengubah kebiasaan lama dengan kebiasaan baru bukan merupakan sesuatu yang mudah. Selain itu, perlu juga suatu panduan, selain dari faslitias bagi guru maupun siswa untuk dapat mengantarkan proses pembelajaran tersebut ke arah yang positif. Derasnya arus informasi saat ini melalui internet, merupakan suatu tantangan bagi siswa agar dapat dengan cepat dan tepat memilah informasi tersebut sesuai kebutuhan terutama dalam proses pembelajaran. Hasil wawancara dengan Kepala Sekolah SMA Islam Global Surya memberikan informasi bahwa siswa di Sekolah tersebut saat ini masih kesulitan untuk dapat mencari sumber rujukannya sendiri via internet. Siswa masih bergantung dari sumber rujukan yang diberikan oleh Gurunya. Maslah utama yang terjadi adalah karena siswa merasa kesulitan dalam mengorganisir sumber-sumber informasi yang ada sehingga siswa menjadi kurang termotivasi untuk dapat memilah sumber informasi yang banyak tersebut. Kurangnya literasi teknologi dan internet juga merupakan suatu hambatan dalam hal ini.

Salah satu solusi agar siswa dapat dengan mudah mengorgansir informasi, baik yang diberikan oleh guru atau dari sumber informasi lainnya di internet, yaitu dengan cara mengintegrasikan sumber belajar yang diperoleh dengan catatan pribadi siswa. Oleh karena itu, sebaiknya catatan pribadi ini dibuat dalam bentu digital dan terkoneksi langsung dengan internet. Salah satu plarform yang dapat digunakan untuk membuat catatan daring yaitu dengan menggunakan Google Site, karena merupakan platform yang mudah digunakan oleh pengguna awam. Siswa dapat membangung laman website mereka sendiri serupa dengan membuat blog dan dengan itu siswa dapat membangun sistem catatan daring mereka sendiri. Pada catatan daring tersebut siswa dapat menyimpan, memilah, dan menemukan kembali dengan mudah bahan ajar, sumber belajar, tugas, soal ujian, dari hasil pembelajaran daring dengan gurunya pada setiap mata pelajaran, terutama pembelajaran matematika.

Kenapa pembelajaran matematika? Karena Matematika merupakan ilmu yang dianggap sulit untuk diajarkan, pada saat pembelajaran luring sekalipun. Selain karena anggapan bahwa materinya sulit, siswa mayoritas mempunyai motivasi yang rendah dalam mempelajari pelajaran matematika (Maskar \& Dewi, 2020; Maskar \& Anderha, 2019; Maskar, 2018). Oleh karena itu, pada saat pembelajaran daring saat ini, guru matematika mempunyai tugas yang cukup berat untuk dapat mentransfer ilmu matematika dengan motivasi belajar yang rendah. Namun, perubahan moda pembelajaran dari luring ke daring seharusnya dapat menjadi momentum bagi guru matematika untuk dapat meningkatkan motivasi belajar siswa dengan metode yang menarik dan terkini dengan melibatkan teknologi dan platform menarik pada proses pembelajaran, salah satunya dengan memanfaatkan Google Site. Pemilihan Google Site sebagai platform dalam PKM ini dikarenakan beberapa hal. Penggunaan Google Site dapat dijadikan sebuah solusi dalam memberikan kemudahan akses informasi. Menurut Ferismayanti (2020) manfaat penggunaan google site secara optimal diantaranya adalah; (1) mengunggah materi pembelajaran, (2) menyimpan silabus, (3) memberikan tugas, (4) memberi pengumuman, dan (5) mengunduh dan melihat tugas siswa.

Berdasarkan data tersebut, penulis berinsiatif untuk mengadakan pelatihan pemanfaatan Google Site sebagai media catatan online pada mata pelajara matematika. Kegiatan pelatihan dilakukan di SMA Islam Global Surya, Kota Bandar Lampung, Provinsi Lampung. 


\section{METODE}

Metode untuk mengukur keberhasilan pelatihan ini menggunakan pengukuran kuantitatif dan kualitatif dengan menggunakan instrumen tes dengan dua tahap tes, yaitu pre-test dan post-test serta penggunakan angket untuk mengetahui respon siswa terhadap penggunaan Google Site tersebut. Adapun tahapan alur pelatihan ini dari mulai persiapan, pengambilan data, dan evaluasi terdapat pada Gambar 1.

Tahap pertama yaitu pengumpulan data. Pada tahap ini, dilakukan pengambilan data berupa hasil tes awal dari 20 orang siswa SMA Islam Global Surya sebagai peserta pelatihan. Selanjutnya dilakukan pelatihan penggunaan Google Site sebanyak empat pertemuan, dilakukan secara daring dan luring. Dalam proses pelatihan apabila belum mencapai hasil yang diharapkan, akan dilakukan pertemuan kelima dan seterusnya sampai seluruh siswa dapat membuat catatan daring sendiri dengan minimal terdapat dua catatan awal pada mata pelajaran Matematika. Selanjutnya pada pertemuan terakhir kembali diambil data melalui tes akhir dan angket respon siswa terhadap pelaksanaan pelatihan. Adapun berikut merupakan tahapan pelaksanaan pelatihan dan indikator pencapaiannya masing-masing terdapat pada Tabel 1.

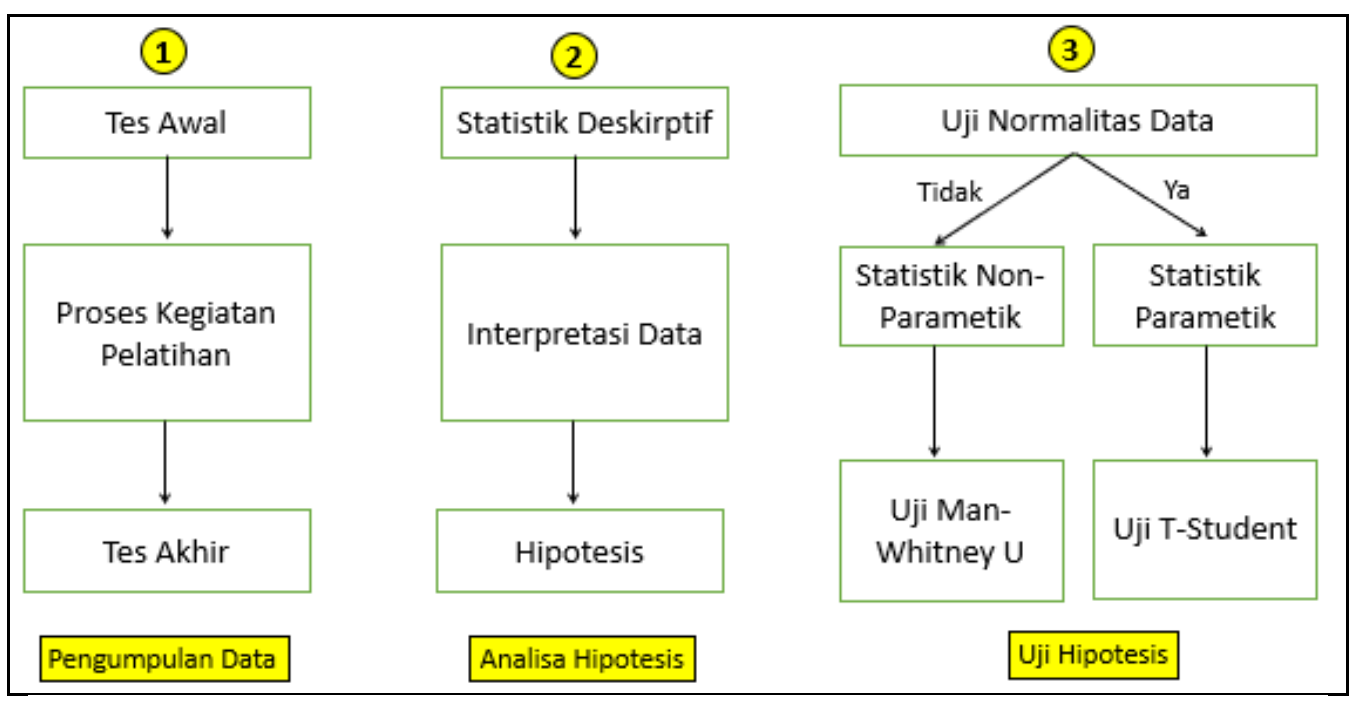

Gambar 1. Diagram Alur Pelaksanaan Kegiatan Pelatihan Catatan Daring Matematika

Tabel 1. Rencana Kegiatan Pelatihan Pembuatan Catatan Daring

\begin{tabular}{|c|c|c|}
\hline No. & Kegiatan & Indikator Pencapaian \\
\hline 1 & $\begin{array}{l}\text { Pre-test } \\
\text { Pembuatan Google Site }\end{array}$ & $\begin{array}{l}\text { Setiap siswa memperoleh } \\
\text { nilai pre-test. } \\
\text { Setiap siswa mempunyai } \\
\text { Google Site. }\end{array}$ \\
\hline 2 & $\begin{array}{l}\text { Pelatihan pemanfaatan Google Site menjadi } \\
\text { Academic Diary pada mata pelajaran matematika. }\end{array}$ & $\begin{array}{l}\text { Setiap siswa mempunyai } \\
\text { Academic Diary pada } \\
\text { Google Site mata pelajaran } \\
\text { matematika. }\end{array}$ \\
\hline 3 & $\begin{array}{lllr}\text { Pelatihan } & \text { pemanfaatan } \text { Google Site menjadi } \\
\text { Academic Diary pada mata pelajaran Bahasa } \\
\text { Inggris. }\end{array}$ & $\begin{array}{l}\text { Setiap siswa mempunai } \\
\text { Academic Diary pada } \\
\text { Google Site mata pelajaran } \\
\text { Bahasa Inggris. }\end{array}$ \\
\hline 4 & $\begin{array}{ll}\checkmark & \text { Post-test } \\
\checkmark & \text { Pengisian angket persepsi siswa terhadap } \\
& \text { pelaksanaan pelatihan. }\end{array}$ & $\begin{array}{lc}\text { Setiap siswa } & \text { memperoleh } \\
\text { nilai post-test. } & \\
\text { Siswa } & \text { memberikan } \\
\text { pendapatnya } & \text { terhadap } \\
\text { pelaksanaan pelatihan. }\end{array}$ \\
\hline
\end{tabular}


Tahap kedua yaitu Analisis Hipotesis. Pada tahap ini dilakukan pengolahan dan analisis data yang telah dikumpulkan pada tahap pertama. Analisis dilakukan menggunakan dua metode, yaitu kuantitatif dan kualitatif. Metode kuantitatif dilakukan untuk data hasil tes (tes awal dan tes akhir) dengan menggunakan teknik statistik deskriptif. Selain itu, metode kualitatif dilakukan untuk data angket respon siswa. Pada bagian analisa kuantitaif, hasil analisa akan dijadikan sebagai hipotesis yang akan diuji kembali pada analisa data statistik inferensial sebelum diambil kesimpulan.

Tahap terakhir adalah Uji Hipotesis. Pengujian ini dilakukan untuk menguji hipotesis yang telah dirumuskan berdasarkan analisa pada pengujian sebelumnya. Uji hipotesis ini menggunakan teknik Statistik Inferensial dengan menggunakan uji perbedaan dua rerata, Uji Independent Sample t-Test atau Uji Mann-Whitney $U$, tergantung normalitas data awal.

\section{HASIL DAN PEMBAHASAN}

Pelatihan telah dilaksanakan selama periode dua bulan, Februari dan Maret, dengan empat pertemuan, satu kali pertemuan luring dan tiga kali pertemuan secara daring. Pada periode tersebut, siswa telah dapat membuat laman untuk catatan daring matematika mereka. Berikut merupakan salah satu catatan daring yang dibuat oleh siswa via Google Site pada Gambar 2.

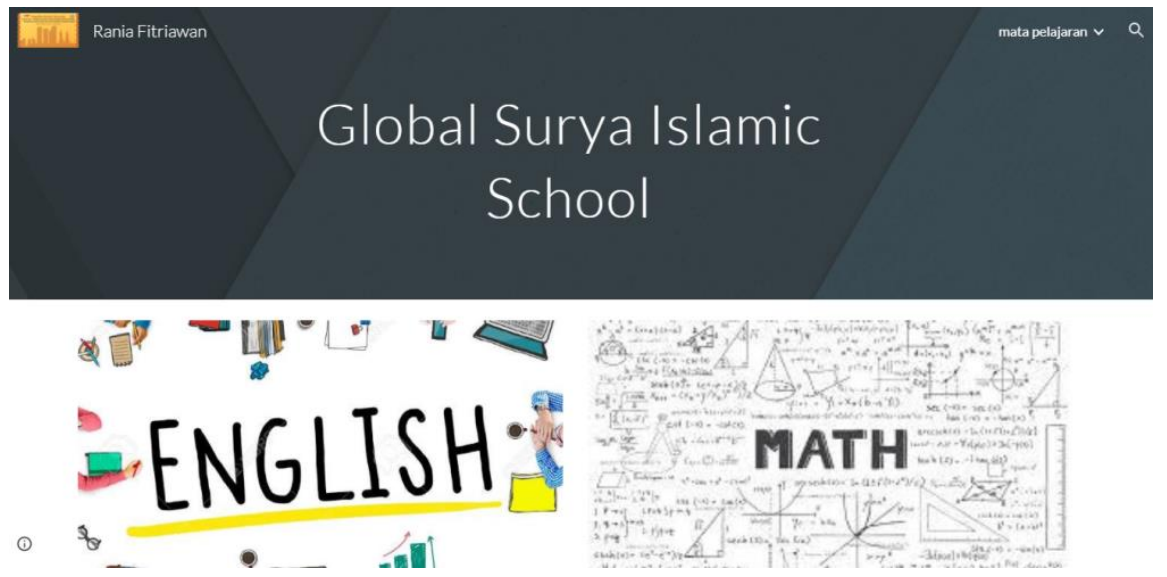

Gambar 2. Hasil Catatan Online Siswa SMA Islam Global Surya

Pelaksanaan pelatihan berjalan dengan baik dan siswa mengikuti pelatihan dengan penuh semangat dan atusias kendati dalam keadaan pademi. Lebih jauh satu pertemuan yang dilaksanakan secara luring dilakukan dengan prokes yang ketat dan ijin dari pihak Sekolah dan Orangtua. Pelaksanaan secara luring juga, walaupun hanya satu pertemuan, diikuti oleh siswa dengan penuh antusias semangat. Adapun Gambar 3 menunjukan proses pelatihan yang telah dilaksanakan.

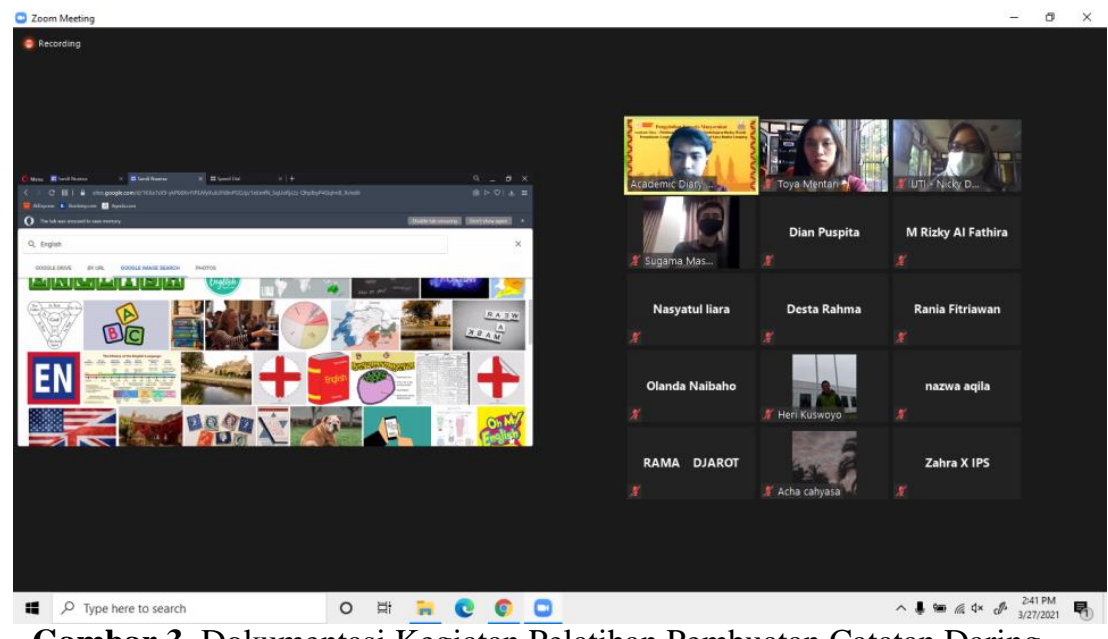

Gambar 3. Dokumentasi Kegiatan Pelatihan Pembuatan Catatan Daring 
Sebagai upaya untuk mengetahui keberhasilan kegiatan pelatihan dan memastikan bahwa siswa dapat memahami tujuan, substansi, dan teknis penggunaan catatan daring terutama pada pembelajaran matematika, penulis melakukan tes awal (pre-test) dan tes akhir (post-test) dan menguji perbedaan kemampuan awal dan akhir tersebut sebagai salah satu bahan evaluasi keberhasilan pelaksanaan pelatihan. Tabel 2 menunjukan nilai rerata tes awal dan tes akhir beserta nilai standar deviasinya.

Tabel 2. Sari Numerik Hasil Tes Awal dan Tes Akhir

\begin{tabular}{lll}
\hline & Mean & Std. Deviasi \\
\hline Pre-Test & 74.6 & 7.48 \\
\hline Post-Test & 84.1 & 7.39 \\
\hline
\end{tabular}

Berdasarkan tabel rerata tes awal sebesar 74.6 dengan standar deviasi sebesar 7.48, dan nilai tes akhir mengalami peningkatan sebesar 9.5 menjadi 84.1 dengan standar deviasi 7.39. Berdasarkan data tersebut, dapat dikatakan bahwa melalui pelatihan ini, pemahaman siswa terkait penggunaan catatan online melalui Google Site meningkat cukup signifikan. Hal tersebut juga didukung oleh nilai simpangan baku atau standar deviasi yang rendah. Artinya tidak terdapat penyimpangan yang tinggi terhadap distribusi nilai per siswa.

Untuk memperkuat analisa tersebut, penulis juga melakukan pengujian lebih jauh mengguakan teknik statistik deskriptif untuk menguji perbedaan dua rerata tersebut. Adapun pengujian akan menggunakan Independent Sample t-Test karena nilai sampel, baik tes awal maupun tes akhir, berdistribusi normal. Berikut merupakan hasil uji-t tersebut terdapat pada Tabel 3.

Tabel 3. Hasil Uji-t Nilai Tes Awal dan Tes Akhir

\begin{tabular}{lll}
\hline & Sig. (P-Value) & Alpha \\
\hline $\begin{array}{l}\text { Compare Mean Pre- } \\
\text { Test \& Post-Test }\end{array}$ & 0.000 & $5 \%$ \\
\hline
\end{tabular}

Berdasarkan hasil uji-t tersebut terlihat bahwa nilai sig. atau P-Value sebear 0.000, dengan nilai alpha sebesar 5\% atau 0.05 , artinya nilai P-Value tersebut memberikan informasi bahwa terdapat perbedaan yang signifikan antara nilai tes awal dan tes akhir, dengan kata lain melalui pelatihan tersebut, terdapat peningkatakn pemahaman yang signifikan bagaiman menggunakan catatan daring, mengenai substansi, tujuan, dan bahkan sampai dengan bagaimana membuat laman catatan daring tesebut.

Instrumen non test pada kegiatan ini berupa angket respon siswa terhadap pemahaman dan respon siswa terhadap proses pelatihan yang telah dilaksanakan. Angket yang diberikan pada siswa terdiri dari 15 pertanyaan dengan delapan indikator yang terdiri dari: Manfaat Blog, Berkomentar di Blog, Membaca Blog, Menulis di Blog, Harapan Blogging, Pengalaman Blogging, Manfaat Google Site, dan Manfaat Teknologi.

Gambar 4 menunjukan grafik hasil instrumen non-test yang telah diisi oleh 20 siswa pada saat pelatihan pertemuan ke-4.

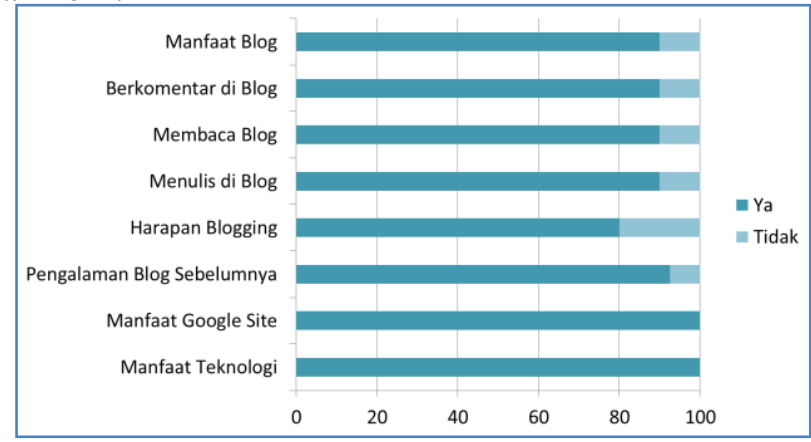

Gambar 4. Hasil Angket Instrumen Non-Test Pelatihan Catatan Daring Matematika 
Gambar 4 menunjukan bahwa mayoritas, lebih dari 80\%) responden atau siswa memberikan jawaban yang positif terhadap setiap pertanyaan pada angket yang diberikan. Bahkan terdapat dua indikator yang memiliki respon $100 \%$, yaitu pada indikator manfaat Google Site dan Manfaat Tenologi. Selain itu, pada indikator lainnya, selain dari harapan blogging, rerata ssiwa memberikan jawaban yang positif dengan persentase sebesar $85 \%$. Persentase paling rendah hanya terdapat pada indikator harapan blogging, yaitu sebesar $80 \%$.

Informasi tersebut menunjukan bahwa mayoritas siswa memberikan respon poisitif terhadap pelaksanaan pelatihan pembuatan dan pemanfaatan catatan daring matematika menggunakan Google Site. Artinya bahwa data angket ini menunjukan siswa telah mempunyai pemahaman yang baik terhadap tujuan dari pemanfaatan catatan daring ini untuk mengoptimalkan pembelajaran daring. Selain itu, siswa juga telah memahami bagimana cara membuat laman catatan daring sendiri yang dilakukan selama pelatihan berlangsung. Siswa juga telah memahami bagaimana menggunakan dan memanfaatkan catatan daring matematika menggunakan Google Site, dimulai dari pengorganisasian dan pengintegrasian antara catatan online yang telah dibuat dengan informasi yang diberikan oleh guru atau informasi lainnya di internet.

\section{SIMPULAN}

Penggunaan catatan daring matematika sebagai salah satu solusi untuk mengoptimalkan proses pembelajaran daring agar siswa dapat mengorganisir catatan dengan baik melalui pengintegrasian antara informasi yang diterima dari guru ataupun dari sumber lain di internet merupakan salah satu solusi yang perlu diperkenalkan pada siswa, terutama pada era pandemi Covid-19 ini. Solusi tersebut di terjemakan oleh penulis dan tim dengan cara melakukan pelatihan pembuatan dan pemanfaatan Google Site sebagai media dan platform catatan daring yang akan digunakan oleh siswa. Pelaksanaan pelatihan telah dilakukan pada 20 siswa SMA Islam Global Surya, Lampung.

Selama proses pelatihan di periode Februari dan Maret 2021 dengan empat pertemuan, siswa telah dapat membuat Google Site mereka masing-masing sebagai media untuk catatan online pribadi siswa tersebut. Selain itu, siswa juga telah memahami bagiamana cara mengintegrasikan catatan online mereka dengan berbagai sumber di internet, baik sumber materi yang diberikan oleh guru maupun sumber lain yang diperoleh oleh siswa melalui internet. Selain itu, siswa juga mendapatkan pelatihan bagaimana mengorganisir sumber informasi tersebut pada laman catatan daring mereka sehingga siswa dapat dengan mudah menemukan kembali atau mengakses sumber yang telah disimpan dengan mudah dan cepat, serta dapat diakses kapan saja dan dimana saja melalui jaringan internet. Lebih jauh, siswa juga diberikan pelatihan mengenai sumber-sumber internet yang relevan dan kredibel yang dapat diakses oleh siswa untuk dapat menunjang pembelajaran mereka. Melalui sumber tersebut, siswa dapat belajar dengan baik, mudah, dan tentu terpercaya.

Hasil pelatihan menunjukan bahwa siswa telah siap dalam menggunakan catatan daring tersebut pada pembelajaran daring di sekolah. Hal tersebut ditunjukan oleh hasil pengolahan dan analisa data nilai tes awal, tes akhir, dan angket yang diberikan pada siswa tersebut selama periode pelatihan. Hasil rerata nilai tes awal dan tes akhir menunjukan bahwa seluruh siswa telah mempunyai pemahaman yang baik terhadap penggunaan catatan daring tersebut, selain itu hasil angket juga memperkuat bahwa para siswa juga mempunyai respon positif terhadap penggunaan media catatan online tersebut.

Lebih jauh, tentu perlu penelitian lebih jauh, agar dapat diketahui sejauhmana efektfitas penggunaan media catatan online tersebut. Oleh karena itu, penulis menyarankan kepada pihak sekolah, terutama di SMA Islam Global Surya agar dapat melakukan penelitian tindakan kelas terhadap efektifitas penggunaan catatan daring tersebut.Sejalan dengan hal tersebut, Mustakim (2020) dalam penelitiannya menyatakan bahwa pembelajaran daring akan menjadi lebih efisien apabila dalam penerapannya guru menggunakan media ajar pendukung selain buku, yaitu media sosial. Selain itu, pelaksanaan pelatihan media pembeljaran juga merupakan cara yang efektif untuk dapat mengoptimalkan suatu proses pembelajaran di Sekolah (Maskar \& Putri, 2021; Puspaningtyas \& Ulfa, 2020). 


\section{SARAN}

Saran ditujukan bagi sekolah ataupun pengajar agar dapat membuat inovasi yang serupa dengan Google Site untuk dapat mengoptimalkan proses pembelajaran daring di tempatnya masing-masing sesuai dengan keadaan dan lingkungan sekolah tersebut. Tentu setiap, tempat mempunyai kendala yang berbeda dari mulai kendala biasa sampai kendala yang mayor. Namun, dengan kreativitas dan sikap pantang menyerah dan kolaborasi yang baik antara lembaga pendidikan, baik dasar, menengah, tinggi, serta pemerintah, proses pembelajaran daring lambat laun dapat diterima oleh insan pendidikan dan berjalan dengan baik.

\section{UCAPAN TERIMA KASIH}

Pengabdian kepada masyarakat ini merupaka Hibah Internal Universitas Teknokrat Indonesia dengan Surat Perjanjian Penugasan Pelaksanaan Pengabdian kepada Masyarakat Nomor 020/UTI/LPPM/ E.1.8/II/2021. Ucapan terima kasih ditujukan kepada Universitas Teknokrat Indonesia dan LPPM Universitas Teknokrat Indonesia atas dukungannya sehingga kegiatan ini dapat berlangsung secara baik dan lancar.

\section{DAFTAR PUSTAKA}

Admin. (2020). Surat Edaran Mendikbud No 4 Tahun 2020 tentang Pelaksanaan Kebijakan Pendidikan dalam Masa Darurat Penyebaran Corona Virus Disease (Covid- 19).Tautan: www.pusdiklat.kemdikbud.go.id, terakhir diakses tanggal 28 Juli 2021.

Ferismayanti. (2012). Mengoptimalkan Pemanfaatan Google Sites dalam Pembelajaran Jarak Jauh Oleh: Ferismayanti, M.Pd. 1-12.

Maskar, S., \& Wulantina, E. (2019). Persepsi Peserta Didik terhadap Metode Blended Learning dengan Google Classroom. Jurnal Inovasi Matematika, 1(2), 110-121. https://doi.org/10.35438/inomatika.v1i2.156.

Maskar, S. \& Dewi, P.S. (2020). Praktikalitas dan Efektifitas Bahan Ajar Kalkulus Berbasis Daring Berbantuan Geogebra. Jurnal Cendekia: Jurnal Pendidikan Matematika, 4 (2), 888-899.

Maskar, S. \& Anderha, R.R. (2019). Pembelajaran Transformasi Geometri dengan Pendekatan Motif Kain Tapis Lampung. Mathema: Jurnal Pendidikan Matematika, 1 (1), 40-47.

Maskar, S. (2018). Alternatif Penyusunan Materi Ekspresi Aljabar untuk Siswa SMP/MTs dengan Pendekatan Pendidikan Matematika Realistik. Prisma, 7 (1), 53-69

Mustakim. (2020). Efektivitas Pembelajaran Daring Menggunakan Media Online Selama Pandemi Covid-19 Pada Mata Pelajaran Matematika the Effectiveness of E-Learning Using Online Media During the Covid-19 Pandemic in Mathematics. Al Asma: Journal of Islamic Education, 2 (1), 1-12.

Puspaningtyas,N.D., Dewi, P.S. (2020). Persepsi Peserta Didik terhadap Pembelajaran Berbasis Daring. JPMI - Jurnal Pembelajaran Matematika Inovatif, 3 (6), 703-712.

Ulfa, M., \& Puspaningtyas, N. D. (2020). The Effectiveness of Blended Learning Using A Learning System in Network (SPADA) in Understanding of Mathematical Concept. Jurnal Matematika Dan Pembelajaran, 8(1), 47-60. 